education is a conscious and comparatively recent attempt to amend and re-shape the patterns so that they may conform more closely to current medical knowledge. There still remains a great deal that is not known about cancer. What is known is that if only people could be persuaded to act in accordance with the considerable knowledge that we do possess, much needless suffering would be avoided and the lives of thousands of people who now die prematurely would be saved."

\footnotetext{
1 Paterson, R., and Aitken-Swan, J., Lancet 1954, 2, 857

2 Aitken-Swan, J., and Paterson, R., British Medical fournal, 1955, 1,623 .

3 Paterson, R., and Aitken-Swan, J., Lancet, 1958, 2, 791.

4 Briggs, J. E., and Wakefield, J., Public Opinion on Cancer: A Survey of Knowledge and Attitudes Among Women in Lancaster 1966. Manchester, Report of Christie Hospital and Holt Radium Institute, 1967.

5 Davison, R. L., British Fournal of Preventive and Social Medicine, $1965,19,24$.

6 Hobbs, P., Public Opinions on Cancer: A Survey of Knowledge and Attitudes Among Women on Merseyside. Liverpool, Report of Merseyside Cancer Education Committee, 1968

7 Williams, E. M., Cruickshank, A., and Walker, W. M., Public Opinion on Cancer: A Report on the Findings of a Survey of Knowledge and Opinions Conducted in Four Areas of South-east Wales. Cardiff, Tenovus Information Centre, 1972.
}

\section{Pollution in Estuaries}

Since earliest times communities have been established along river banks, as the river provided a water supply and also a convenient means for the disposal of waste products. When industrial plants were being established which produced considerable quantities of trade effluents, it seemed reasonable to site them close to a tidal estuary on the assumption that the effluents would be rapidly dispersed to the open sea. This is now known not to happen, and most of our estuaries have a build up of pollution which falls with the ebb, only to return with the incoming tide. Moreover, pollutants such as mercury, lead, and cadmium settle in the estuarial mud and become a "deposit bank" which destroys marine and plant life. Concentration of organic mercury in marine organisms has led to outbreaks of mercury poisoning in Japan.

The pollutants discharged into estuaries originate from two main sources-industrial waste and sewage. The former may be toxic, while heavy discharges of sewage will contain pathogenic micro-organisms. The contamination is apt to destroy the amenities of the waterfront, and the toxic substances may completely destroy the marine life and damage birds and fish. There are two attitudes to pollution of this kind. The emotional reaction is to demand that the contamination should be stopped whatever the economic consequences. The opposing view is to play down the harm being caused, and to point out that the estuary serves mainly as a water highway and is beneficial to industry as easy discharge of effluent reduces costs. The conclusion of the recently published report of the Royal Commission on Environmental Pollution ${ }^{1}$ lies between these two views. It states, "However desirable it would be to remove contamination from estuaries, there is a practical limit to the burden which should be placed on the community to achieve this aim." The report also emphasizes that even if its recommendations for immediate improvements are put in motion it may take some time, even years, before the damage caused by past pollution will be overcome.

So far as infection is concerned, it is only occasionally that immersion in estuarial water is implicated as the source of salmonella infection, and from time to time cases of Weil's disease have been reported in persons falling into polluted docks. While sewage pollution of bathing beaches is aesthetically offensive, it has been held not to constitute a serious risk of infection. ${ }^{2} 3$ However, some recent research carried out at the American University School of Medicine, Beirut, would appear to cast some doubt on this finding. N. H. Nabbut and F. Kurayiyyah ${ }^{4}$ tested the viability of Salmonella typhi in sea water under various conditions. They consider that bathing in sewage-polluted sea water carries with it a risk to health in spite of the sea's dilution of pathogens and rapid self-purification. They state that this purifying process is incapable of coping with massive pollution problems and should not be relied on as the sole protection offered to bathers. Though "holiday typhoid" is featured prominently in a recent Health Department publication on typhoid and paratyphoid fevers, ${ }^{5}$ it has assumed that these infections are food-borne, and sea bathing is not mentioned as a source of infection.

In the past estuaries were important to maritime trade and industry. Today, with their increasing use for sports such as yachting, water-skiing, and other aquatic activities, the health dangers from pollution should be reassessed.

1 Royal Commission on Environmental Pollution, Third Report, Pollution in Some British Estuaries and Coastal Waters, Cmnd. 5054 London, H.M.S.O., 1972

2 Medical Research Council, Sewage Contamination of Bathing Beaches in England and Wales. Memorandum No. 37. London, H.M.S.O.,

3 Committee on Bathing Beach Contamination of the Public Health Laboratory Service, fournal of Hygiene, 1959, 57, 435.

4 Nabbut, N. H., and Kurayiyyah, F., fournal of Hygiene, 1972, 70, 223

5 Central Health Services Council, Typhoid and Paratyphoid Fevers, Executive Council Letter No. 118/72. London, Department of Health and Social Security, 1972.

\section{Coventry Meeting}

In the last few years the scope of the Annual Clinical Meetings of the B.M.A. has been extended by holding them jointly with various associations and societies. In 1969 the first clinical meeting was held overseas, in Malta, G.C., and last year the principles of a joint meeting and an overseas location were combined at the Annual Clinical Meeting in Cyprus. Next year will see two further innovations: the participation of a European association-the Danish Medical Association-and also, on the final day of the meeting, of the Junior Members Forum.

Besides the usual full programme (Supplement, p. 49) to bring doctors up to date with recent developments in such topics as immunotherapy of cancer, coronary insufficiency, and treatment of duodenal ulcer, the forthcoming British and Danish entry into the Common Market will be recognized by two symposia on undergraduate and further medical education in the E.E.C. A full social programme has been arranged and visitors can be assured of a warm welcome which the Midlands traditionally extend to those not fortunate enough to live in the heart of England.

The opportunity of attending refresher symposia in which world authorities will participate, of meeting colleagues from a country with many traditional links with Britain, and of visiting the Shakespeare country is one which many doctors will rightly not want to miss. They are urged to make their bookings early. 